УДК: 378.6:62]:37.014.6

\title{
CHARACTERISTICS OF A TECHNICAL UNIVERSITY EDUCATIONAL ENVIRONMENT IN THE CONTEXT OF THE INTELLECTUAL MOBILITY DEVELOPMENT
}

\author{
G. E. Mikhnenko \\ Kyiv, National Technical University of Ukraine \\ "Kyiv Polytechnic Institute" \\ galynka@yandex.ru
}

\begin{abstract}
The article deals with the characteristics of the modern educational environment of a technical university and its role in the development of intellectual qualities of future engineers, among which is intellectual mobility. The concept "environment" and the structure of an educational environment are considered. Much attention is given to understanding the modern educational environment of a technical university as a holistic system and synergistically organized area of interaction between all the participants of the educational process, which helps to develop intellectual qualities of future engineers, necessary in a knowledge-based society. Together with intellectual responsibility and intellectual intuition, one of such personality qualities is intellectual mobility, which makes it possible for a professional to change quickly the types of intellectual activity without reducing its efficiency. The author distinguishes the following characteristics of a technical university educational environment: deep integration of educational, scientific and innovative processes; communicativeness which means the optimization of an educational process by all of its participants, subject-to-subject interaction between a teacher and a student, wide implementation of information technologies, and the ability of the environment for selfdevelopment and self-renewal. It is concluded that the environment is an active participant of the educational interaction: it is both a process and a result of individual activities.
\end{abstract}

Key words: educational environment, intellectual mobility, communication, integration.

Introduction. Globalisation and accelerating pace of technological changes in the Information Age force governments, academic institutions, and employers to rethink together the traditional approaches in the field of higher education. It is an important step towards a more flexible educational system aimed at recognizing the changes in a knowledge-based society, with an increased mobility of people. On the one hand, the key role in training the highly-qualified specialists belongs to universities, especially technical ones. On the other hand, even the best university can not provide future engineers with all the knowledge necessary for them during their lives. Here appears the problem: it is important to teach a student to learn independently and be ready for life long learning, while acquiring information and using it appropriately. V. Andrushchenko points out that it is a university that has to develop the intelligence of a nation [7].

Scientists consider intellectualization in the $21^{\text {st }}$ century as a new paradigm of education, based on humanization and informatization. According to G. Egorova [4], intellectualization is a goal-oriented systemic process directed at the development of intellectual culture of a personality, which leads to significant changes of both an individual and a society. Intellectual culture provides personality and professional capability and success by the following indicators: high competitiveness of a future 
engineer; intellectual intuition; intellectual responsibility; intellectual mobility; intellectual activity; intellectual competence.

Engineering is a dynamic profession. A challenge for the engineering profession is the increasing diversity of the disciplines which are gathered under the banner of engineering. Hence, the demands for the qualitative training of technical universities graduates stipulate the necessity to develop personality traits, especially intellectual qualities characterized by mobility.

It is known that the issue of the intellectual development of an individual, his/her capabilities was and has been investigated by such outstanding scientists, as L. Vygotsky, S. Rubinstein, M. Kholodnaya. The important characteristic of intelligence is its mobility. In the context of investigations devoted to the problems of mobility (O. Bilyk, E. Ivanchenko, A. Nelepova, T. Kotmakova, L. Khorunzha, R. Prima) there appeared the issue of the development of intellectual mobility defined by us as an integrated characteristic (quality) of a personality which combines intellectual capabilities and personality traits in a system that ensure the readiness of a specialist to find and effectively apply required information, to act promptly and choose the best methods of solving both reproductive and creative tasks as well as change quickly the types of intellectual activity without reducing its efficiency.

In fact, in a knowledge-based society the graduate attributes will be changing all the time. As a result, in education the issue of seeking new thinking strategies and behaviour patterns is actualised; at the same time, the key role in teaching belongs not only to the curriculum, but to the educational environment and teaching methods [7].

The aim of this paper is to study the essential characteristics of a technical university educational environment and determine its role in the development of intellectual mobility of future engineers.

Characteristics of an educational environment of a technical unviersity. The importance of an educational environment is considered in investigations of modern educational philosophy (B. Gershunskyi, I. Zyazyun) and personalityoriented educational process (I. Bekh, I. Yakimanskaya). Certain aspects of educational environments are researched by N. Gontarovska, T. Ravchyna, etc.

In general, "environment" means the surroundings or conditions in which a person lives. Any person, as an active individual, is both a product and a creator of the environment. This philosophical, psychological and pedagogical understanding of the interdependence of the personality development and environment became the basis for the scientific approaches to the creation of an educational environment.

The influence of a teacher on the development of a young person happens by organizing appropriate environment and interaction of a personality with it. The idea of determinism by S. Rubinstein is considered to be a principle of complicated relations between external and internal at different stages of the personal development in the surrounding environment. The influences of the environment, carried inside, become the qualities of a person and are dynamic by character [2]. It is from inside the environment that the impact on a personality takes place.

Thus, the educational environment is a multilevel system of psychological and pedagogical conditions that enable the development of capabilities and personality traits of its participants. The concept of educational environment is complex, which leads to various approaches to determination of its content, structure, and functions. 
T. Ravchyna [5] defines the educational environment as an integral social and psychological area that involves the area of conditions, interconnections, goals and intentions, relations and positions, always hierarchically structured. Educational environment of an educational establishment, a technical university in particular, is determined by interpersonal interactions and social contacts, system of communicative means and information, educational impacts and processes.

In the structure of an educational environment, researchers identify the following dialectically interacted components: 1) space-semantic: architectural and esthetic organization of the area, symbols (coat of arms, traditions); 2) methodological: content sphere (educational concepts, syllabuses, textbooks, etc.) and teaching methods; 3) communicatively organisational: participants of an education environment (statuses, roles, values), communicative and teaching styles, organisational conditions (management culture, associations and clubs, etc.) [1].

At present, system approach and synergy theory are applied to research educational phenomena (V. Andrushchenko, E. Luzik, etc.). Synergy theory studies the open type systems, whose principles are self-organisation and self-regulation. Open systems constantly interact with environment and other systems. The personal development depends greatly on the type of the systems (open or closed) which influence the individual experience. In order to successfully develop a personality it is necessary to ensure that there is an open interaction between the personalities and their environment. In accordance with system and synergy approach, university can be considered as an intellectual system which orients students towards various types of intellectual activities and has its internal structure that includes a high number of different processes, subsystems, connections and interactions.

The important component of personal intelligence development is the traditions of such an intellectual system, a student being an element of it. These traditions become both the form of the fixation of intellectual experience and the sphere in which the experience is revealed. Among these forms are the students' conferences, competitions, meeting with prominent scientists and statesmen. We agree with G. Egorova [4] who states that the level of intelligence development is shown in intellectual activity, intellectual mobility, responsibility, competence, intuition, in intellectual skills of a student, his belief in necessity of intellectual self-improvement. The source and condition for the personal intellectual development is the intellectual space of a technical university educational environment; the latter must be as variable and creative as possible. The researcher considers an intellectual educational environment of a technical university as a holistic system and synergistically organized area of interaction between the educational process participants and social environment, which helps to develop personal intellectual qualities.

The intellectual educational space is based on subject-to-subject, subject-toobject interaction and intellectual educational centres which are responsible for holding conferences, creative projects, contests, exhibitions, etc. The National Technical University of Ukraine "Kyiv Polytechnic Institute" (NTUU "KPI") has a number of centres to carry out scientific investigations, namely, the Science Park "Kyiv Polytechnic", Supercomputer centre, World Data Centre, Nanoelectronics and Nanotechnology Centre, etc. The university has proclaimed "education-scienceinnovations" to be the basis for the training of future engineers. In accordance with 
this strategy, all university subdivisions are focused on: a) deep integration of education, science and innovations; b) improving the level of quality of teaching staff and contingent of students; c) enhancing the fundamental and practical training; d) implementation of new teaching methods and technologies. Furthermore, NTUU "KPI" regularly monitors residual knowledge of its students, analyses employers' references, and improves information systems in training. The chancellor of "KPI" M. Zgurovsky points out that NTUU "KPI" should be the main link of society by means of which the whole chain of modern science and education can be drawn [3].

Thus, the major characteristic of a technical university educational environment is the deep integration of educational, scientific and innovative processes, closed cooperation with technological labour market. We state that only by integrating education, science and innovations it is possible to create the conditions for the development of personality qualities of engineers-intellectuals.

Here we can not but mention one more main characteristic of a modern education environment - communicativeness. The scientists from Belarus [6], while working on the concept of a new university in unguaranteed circumstances, state that the environment is a product of cooperative construction in actual communication, i.e. both the process and the result of personal activities. The objective of education is the organisation of communication between students and cultural texts, the work with information. The educational environment is a communicative phenomenon, directed at the experience differentiation. The main feature of an educational environment is concentration of educational efforts not only on the student's personality or material conditions, but on the specific forms of communication.

In fact, a traditional university discourse is characterized by monologic communication (both between students and a teacher, and in the interaction with educational texts) where professor's/ author's words can not be doubted, therefore dialogue is not allowed. On the other hand, multilateral communication in educational process means participation of all its parts. In this case, the relationships between a student and a teacher are being changed; education is decentralised; scientific competence is replaced with communicative one; the function of education is transformed into the task to support a student [6].

In the Information Age people are overloaded with information, so the ability to acquire knowledge comes to dealing with increasing data volume. The world is constantly changing; therefore the position of a university teacher is becoming different too. He is not a transmitter of knowledge, but a creator of circumstances for a student to work independently, to process information quickly and act promptly in unconventional situations, i.e. to display a certain level of intellectual mobility.

The student's position of a knowledge receiver is being changed into the position of a builder of his/her own knowledge and personal professional programme. Unfortunately, one should note that, being aware of these changes, our students are passive and do not have the basic skills to realize them. Not only university administration, but every teacher has to be responsible for the creation of such an educational environment that could ensure the personality development of future engineers. The building of situations of uncertainty, e.g. teacher's refusal to give the answer to students' question, then carrying out interactive seminars, psychological 
consultations, applying new educational technologies will help in this. Scientists state, that "on the agenda there is the comprehensive review of the stated concepts, the change of educational paradigm, related to reformation of thinking" [7, p. 2].

Communicativeness also means a wide range of application of computer technologies in the educational process, which will result in the appearance of the knowledge of new quality, multileveled and multicomponent [6]. But the availability of computing equipment does not ensure that the world outlook of information society will be formed. It is possible only by means of specifically designed educational programmes and Internet navigation. For example, NTUU "KPI" has assigned its teaching staff the important task: to finish the work on 'E-campus' and make sure all the teachers and students use this system.

Hence, information character of the modern educational environment of a technical university is one of its most important characteristics. It is necessary to accept it not only for researching the content of an educational environment, but also for practical applications and education development in Information Age.

Discussion. Organisation of an educational process in the context of the new educational paradigm - intellectualization - is possible when an educational environment of a university, on the one hand, corresponds to the modern trends in industry and technology, but, on the other hand, provides the conditions for intelligence development of students. The educational environment of a technical university is considered to be a holistic system and synergistically organized area of interaction between the participants of the educational process, which helps to develop intellectual qualities of future engineers, necessary in a knowledge-based society. Together with intellectual responsibility and intellectual intuition, one of such personality qualities is intellectual mobility, which makes it possible for a professional to change quickly the types of intellectual activity without reducing its efficiency.

The defining characteristics of a technical university educational environment are as follows: deep integration of educational, scientific and innovative processes; communicativeness which means the optimization of an educational process by all of its participants, subject-to-subject interaction between a teacher and a student, wide implementation of information technologies, and the ability of the environment for self-development and self-renewal. The environment is also an active participant of the educational interaction: it is both a process and a result of individual activities.

The factors of an educational environment that can be effective for the development of intellectual mobility of future engineers need to be studied further.

\section{ЛIТЕРАТУРА}

1. Габа I. М. Освітне середовище: соціально-психологічна парадигма / I. М. Габа // Актуальні проблеми психології. - Т.7. - К., 2010. - С. 27-31.

2. Гонтаровська Н.Б. Теоретичні i методичні засади створення освітнього середовища як фактору розвитку особистості школяра: автореф. дис. ... д-ра пед. наук: 13.00.07 / Н. Б. Гонтаровська; Інститут проблем виховання НАПН України. - К.: 2012. - 44 с. 
3. Доповідь ректора НТУУ “КПІ”, академіка НАН України М.3. Згуровського на сесії науково-педагогічних працівників 29 серпня 2013 р.[Електронний ресурс] - Режим доступу: http://reserv.kpi.ua/en/node/9067

4. Егорова Г. И. Интеллектуализация профессиональной подготовки специалиста технического вуза: дис. ... д-ра пед. наук: 13.00 .08 [Електронный ресурс] / Г. И. Егорова. - Санкт-Петербург, 2005. - 407 с.

5. Равчина Т. В. Організація взаємодії студентів з освітнім середовищем у вищій школі / Т. В. Равчина // Вісник Львівського університету. Серія педагогічна. - 2005. - Вип. 19. - С. 3-16.

6. Университет как центр культуропорождающего образования. Изменение форм коммуникации в учебном процессе : монографія [Електронний peсурс] / М. А. Гусаковский, Л. А. Ященко, С. В. Костюкевич и др.; Под ред. М. А. Гусаковского. - Мн.: БГУ, 2004. - 279 с.

7. Філософсько-методологічні засади підвищення якості вищої освіти України: європейський вимір / авт. кол. : В. Андрущенко (кер.), М. Бойченко, Л. Горбунова, І. Надольний та ін. - К. : Педагогічна думка, 2012. - 220 с.

\section{REFERENCES}

1. Haba, I. M. (2010). Educational environment: social and psychological paradigm. Aktualni problemy psyholohii, 7, 27-31 [in Ukrainian].

2. Gontarovska, N. B. (2012). Theoretical and methodological basics of creating an educational environment as a factor of a student's personality development. Extended abstract of Doctor's thesis. Kyiv [in Ukrainian].

3. Zgurovsky, M. Z. (2013). The report of the chancellor of NTUU "KPI", academician of NAS of Ukraine at the session of scientific and pedagogical staff, August, 29, 2013. Retrieved from http://reserv.kpi.ua/en/node/9067 [in Ukrainian].

4. Egorova, G. I. (2005). Intellectualization of professional training of a technical university specialist. Doctor's thesis. St. Petersburgh [in Russian].

5. Ravchyna, T. V. (2005). Students' interaction with educational environment at higher school. Visnyk Lvivskoho universytetu, Seriia pedahohichna, 19, 3-16 [in Ukrainian].

6. Gusakovskiy, M. A. (Ed.) (2004). University as a centre of culture generating education. The change of the communication forms in educational process. Minsk: BGU [in Russian].

7. Andrushchenko, V. P., Bekh, V. P. Boichenko, M. I., Gorbunova, L. S., Nadolny, I. F., Luzik, E. V., ... Yaroshovets, V. I. (2012). Philosophical and methodological basis for improving the quality of higher education of Ukraine: European aspect. Kyiv: Pedahohichna dumka [in Ukrainian].

\section{Г. Е. Міхненко. Характерні риси освітнього середовища технічного університету в контексті формування інтелектуальної мобільності. \\ У статті розглядаються особливості освітнього середовища технічного університету} та його роль у формуванні особистісних якостей майбутніх інженерів, інтелектуальної мобільності зокрема. Аналізується поняття «середовище», представлено структуру освітнього середовища. З'ясовано важливість розуміння інтелектуально-освітнього середовища технічного університету як цілісного системно-синергетично організованого інтелектуально-освітнього простору взаємодії учасників освітнього процесу, що дозволяє розкрити та сформувати інтелектуальні якості майбутніх інженерів, необхідні у сучасній ситуації глобальних трансформацій. Поряд 3 інтелектуальною відповідальністю, інтелектуальною активністю, однією 3 таких особистісних якостей $€$ інтелектуальна мобільність, що визначається автором як інтегрована особистісна якість, що забезпечує готовність фахівця швидко віднаходити й застосовувати інформацію, оперативно обирати ефективні способи виконання завдань як репродуктивного, так і творчого характеру та 
швидко змінювати види та форми інтелектуальної діяльності без зниження ефективності та результативності останньої. Автором визначені характерні риси сучасного освітнього середовища технічного університету, а саме: глибока інтеграція навчального, наукового та інноваційного процесів; комунікативність освітнього середовища, що передбачає участь всіх суб'єктів у конструюванні та оптимізації освітнього процесу, суб'єкт-суб'єктну взаємодію викладача й студентів, широке впровадження у навчально-виховний процес інформаційних комп'ютерних технологій, а також здатність середовища до саморозвитку й самооновлення. 3'ясовано, що освітнє середовище виступає продуктом спільного конструювання у межах актуальної комунікації: воно $є$ і процесом, і результатом власної діяльності індивіда. взаємодія.

Ключові слова: освітнє середовище, інтелектуальна мобільність, комунікація

Г.Э. Михненко. Характерные черты образовательной среды технического университета в контексте формирования интеллектуальной мобильности.

В статье анализируется роль образовательной среды технического университета в формировании личностных качеств будущих инженеров, в частности - интеллектуальной мобильности. Определены следующие основные особенности современной образовательной среды технических университетов: глубокая интеграция учебного, научного и инновационного процессов; коммуникативность образовательной среды, которая предусматривает участие всех ее субъектов в создании и оптимизации образовательного процесса, субъект-субъектное взаимодействие преподавателя и студента, широкое внедрение информационных компьютерных технологий в учебно-воспитательный процесс, а также способность среды к саморазвитию и самообновлению. Выявлено, что образовательная среда является продуктом совместного конструирования в пределах актуальной коммуникации: она является и процессом, и результатом собственной деятельности индивида.

Ключевые слова: образовательная среда, интеллектуальная мобильность, коммуникация, взаимодействие. 